\title{
BIOGEOCHEMISTRY OF IRON IN SEAWATER
}

\author{
KUMA KENSHI \\ Graduate School of Fisheries Sciences, Hokkaido University
}

\section{INTRODUCTION}

Section 1 and 2 of this paper focus on the equilibrium chemical speciation of iron in seawater and the distributions of iron in oceanic waters, respectively. Section 3 focuses at the cellular level, looking at the way in which iron is taken up by marine phytoplankton, and at the relationship between iron chemistry in seawater and its uptake. In section 4, we suggest that the natural dissolved organic-Fe(III) complexes supplied from the Amur River into the Okhotsk Sea may play an important role in supplying bioavailable iron and inducing the high primary production in the Okhotsk Sea.

\section{IRON CHEMISTRY IN SEAWATER}

Iron chemistry, such as inorganic speciation and organic complexes, in seawater is very complex and not yet fully understood. The inorganic speciation of $\mathrm{Fe}$ (III) in seawater is dominated by its hydrolysis behavior and ready tendency to nucleate to particulate $\mathrm{Fe}$ (III) hydroxides. In general, iron in oxic seawater around $\mathrm{pH} 8$ is present predominantly in the particulate iron oxyhydroxide, which has an extremely low solubility, and thermodynamically stable 3+ oxidation state (Fig. 1, Stumm and Morgan, 1996; Waite, 2001). Numerous studies of both the solubility of iron in seawater and of the detailed hydrolysis behavior of $\mathrm{Fe}$ (III) as a function of $\mathrm{pH}$ have been undertaken over the last 25 years. However, there are discrepancies between the estimated concentrations of dominant hydroxo-complex species of $\mathrm{Fe}(\mathrm{III})$, such as $\mathrm{Fe}(\mathrm{OH})_{2}{ }^{+}, \mathrm{Fe}(\mathrm{OH})_{3}{ }^{\circ}$ and $\mathrm{Fe}(\mathrm{OH})_{4}{ }^{-}$, and values $(\sim 0.1-10 \mathrm{nM})$ for the thermodynamic solubility of $\mathrm{Fe}(\mathrm{III})$ hydroxide in seawater (e.g. Byrne and Kester, 1976; Kuma et al., 1996; Liu and Millero, 2002). Recent studies of the Fe(III) hydroxide solubility in seawater suggest that the Fe(III) solubility is controlled by organic complexation (Kuma et al., 1996; Millero 1998; Liu and Millero, 1999, 2002; Waite, 2001; Tani et al., 2003), which, subsequently, regulates dissolved iron concentrations in seawater (Kuma et al., 1998, 2003; Johnson et al., 1997a, b; Archer and Johnson, 2000; Nakabayashi et al., 2001). In addition, many studies of iron speciation in seawater using competitive ligand equilibration/cathodic stripping voltammetry (CLE/CSV) measurement have pointed out that Fe-organic complexation is prevalent in seawater (e.g. Rue and Bruland, 1995, 1997; Gledhill et al., 1998; Boye et al., 2001).

In general, the dissolved Fe concentrations in the surface mixed layer were lower than those in mid-depth and deep waters and the values of Fe(III) solubility in the surface water, resulting from the active biological removal of dissolved $\mathrm{Fe}$ and excess concentration of Fe-binding organic ligands (e.g. Rue and Bruland, 1995, 1997; Kuma et al., 1996, 1998; 
Nakabayashi et al., 2001, 2002). In addition, it has been reported that Fe(III) solubility in the surface mixed layer is generally high and variable, with the higher values sometimes corresponding to the depth of high chlorophyll $a$ concentration (Kuma et al., 1996, 1998; Nakabayashi et al., 2001, 2002), probably resulting from a higher concentration or stronger affinity of natural organic Fe(III) chelators, which may be released by some phytoplankton or cyanobacteria (Wilhelm and Trick, 1994; Boye and van den Berg, 2000, Witter et al., 2000).

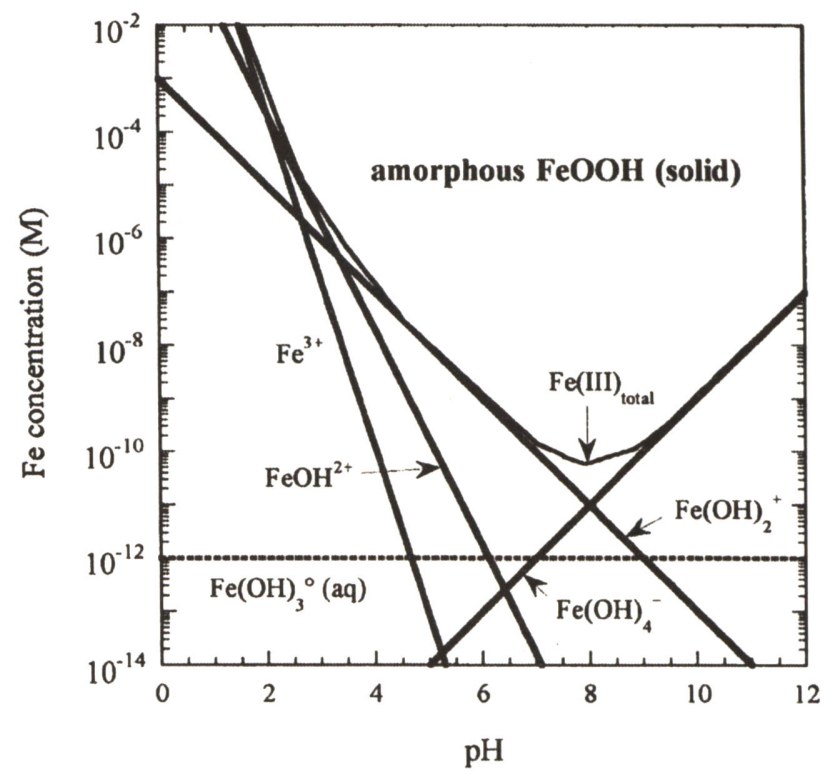

Fig. 1 Iron solubility of solid amorphous $\mathrm{FeOOH}$ (Stumm and Morgan, 1996)

\section{Vertical distributions Of IRON IN THE NORTHWESTERn NORTH PACIFIC OCEAN}

In our study, three stations, $\mathrm{A} \quad\left(50^{\circ} \mathrm{N}, 165^{\circ} \mathrm{E}\right), \mathrm{B}\left(40^{\circ} \mathrm{N}, 165^{\circ} \mathrm{E}\right)$ and $\mathrm{C}\left(44^{\circ} \mathrm{N}, 155^{\circ} \mathrm{E}\right)$ were made up the spatial study of vertical iron distributions (Fig. 2). The oceanographic regime at the surface changed dramatically from oligotrophic waters at lower latitude to eutrophic waters at higher latitude. Vertical profiles of salinity, temperature and nutrient at stations A, B, and C indicated a subarctic water mass (center of the Western Subarctic Gyre (WSG), in which there is massive upwelling leading to excess major nutrients) with low salinity, low temperature and high nutrient, a subtropical water mass (North Pacific Current front) with high salinity, high temperature and low nutrient, and the boundary region (near western edge of the WSG), respectively. The macronutrient concentrations such as $\mathrm{PO}_{4}$ in the surface layer were high in the subarctic current system and low in the subtropical current system (Fig. 3a, 3b). In the subarctic water region in the northern North Pacific, an upward flow toward the north is generally known as the final arrival point of the deep water circulation from the vertical profiles of salinity and nutrients (e.g. Kuma et al., 1998).

At station A (an upwelling area in the subarctic region), $\mathrm{Fe}(\mathrm{III})$ solubility was relatively low and constant in the surface mixed layer (0-100 m depth) (Fig. 3a). Below the surface mixed layer, however, Fe(III) solubility and nutrient levels rapidly increased at 100-150 m 
depth and varied little with high constant values in mid-depth waters (150-1250 m) due to massive upwelling at the center of the WSG. In addition, the dissolved Fe concentrations at $100-150 \mathrm{~m}$ depth suddenly increased from $0.2 \mathrm{nM}$ to $0.7-0.9 \mathrm{nM}$, consisting with the rapid increase in $\mathrm{Fe}$ (III) solubility and nutrient concentrations within this narrow depth range and then high constant values in mid-depth waters. At station B and C (subtropical and boundary regions, respectively), the Fe(III) solubility had minimum value at 75-200 m depth, below the surface mixed layer (Fig. 3b, 3c). The subsequent solubility levels in mid-depth water increased up to $0.6-0.7 \mathrm{nM}$ with increasing nutrient concentrations and had high constant values at 600-2000 m depth at station B and 300-1000 m depth at station C. In deep waters ( $\geq 1000 \mathrm{~m}$ depth) at all stations, Fe(III) solubility tended to decrease slightly to $0.4-0.5 \mathrm{nM}$ with depth in association with the decrease in nutrients (Fig. 3). In general, the vertical profiles of phosphate and nitrate indicate shallow water regeneration while silicate has a deeper regeneration cycle leading to a deeper maximum (Millero, 1996). It has been reported that the increasing $\mathrm{Fe}(\mathrm{III})$ solubility with nutrient concentrations is likely related to the decomposition and transformation of sinking organic matter, rather than the dissolution of silicate, in intermediate water (Kuma et al., 1998). In addition, dissolved Fe had nutrient-like profiles characterized by surface depletion and deep enrichment (Fig. 3b, 3c). The dissolved Fe profiles generally show low concentrations at the surface $(0.1-0.4 \mathrm{nM})$, abroad maximum from $500 \mathrm{~m}$ to $1000 \mathrm{~m}(0.8-1.2 \mathrm{nM})$, and decreasing concentrations with depth below $1000 \mathrm{~m}$ to $0.8-0.9 \mathrm{nM}$ at $3000-3500 \mathrm{~m}$ depth. The vertical profiles are similar to those of $\mathrm{Fe}$ (III) solubility, suggesting that dissolved Fe concentrations in deep ocean waters are controlled primarily by the $\mathrm{Fe}(\mathrm{III})$ complexation with natural organic ligands, which were released through the oxidative decomposition and transformation of biogenic organic matter in mid-depth and deep waters. This process must be also responsible for the similarity in vertical distributions of nutrient, such as nitrate and phosphate, and dissolved Fe which were released through the remineralization of biogenic particles.

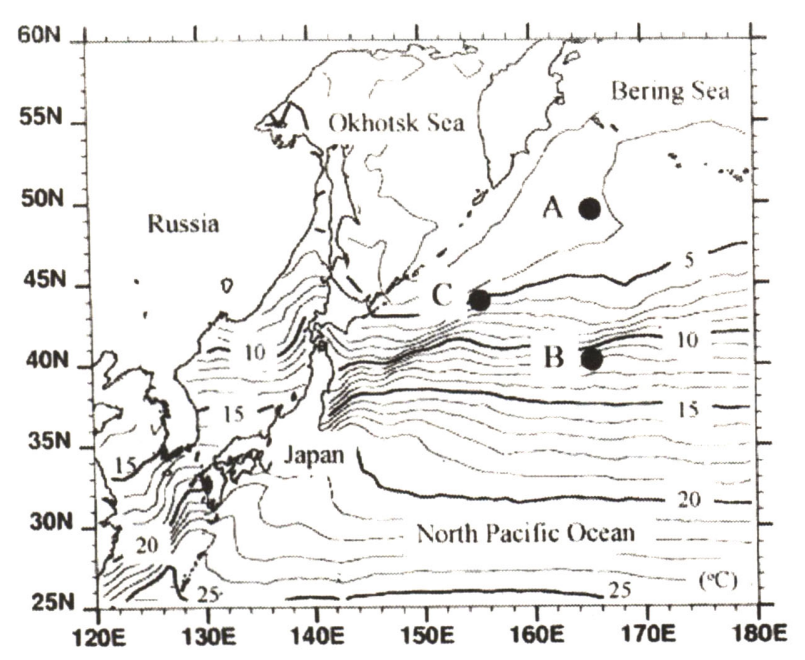

Fig. 2 Location of stations $\mathrm{A}\left(50^{\circ} 00^{\prime} \mathrm{N}, 165^{\circ} 00^{\prime} \mathrm{E}\right)$ in the subarctic region, $\mathrm{B}\left(40^{\circ} 00^{\prime} \mathrm{N}, 165^{\circ} 00^{\prime} \mathrm{E}\right)$ in the subtropical region, and $\mathrm{C}\left(44^{\circ} 00^{\prime} \mathrm{N}, 154^{\circ} 59^{\prime} \mathrm{E}\right)$ in the boundary zone between subarctic and subtropical regions in the northwestern North Pacific Ocean during May 1999. 
The chemical composition of natural organic Fe(III) chelators in deep waters may differ from those that were released by phytoplankton or bacteria species through their metabolism in the surface waters although the chemical composition are still unknown. It has been suggested that fluorescent humic substances are regenerated in the water column by the oxidation and remineralization of settling organic particles (Hayase and Shinozuka, 1995) and that the complexation of iron with natural organic ligands, such as humic acid, increase the iron solubility at $\mathrm{pH}$ levels near 8 (Liu and Millero, 1999). In addition, we found the most significant correlation between the Fe(III) solubility and humic-type fluorescence intensity in intermediate and deep waters in the northwestern North Pacific Ocean and Okhotsk Sea, suggesting that the distribution of marine humic-type fluorescent organic matter may control the distributions of $\mathrm{Fe}(\mathrm{III})$ solubility and dissolved Fe concentrations in deep waters (Tani et al., 2003).

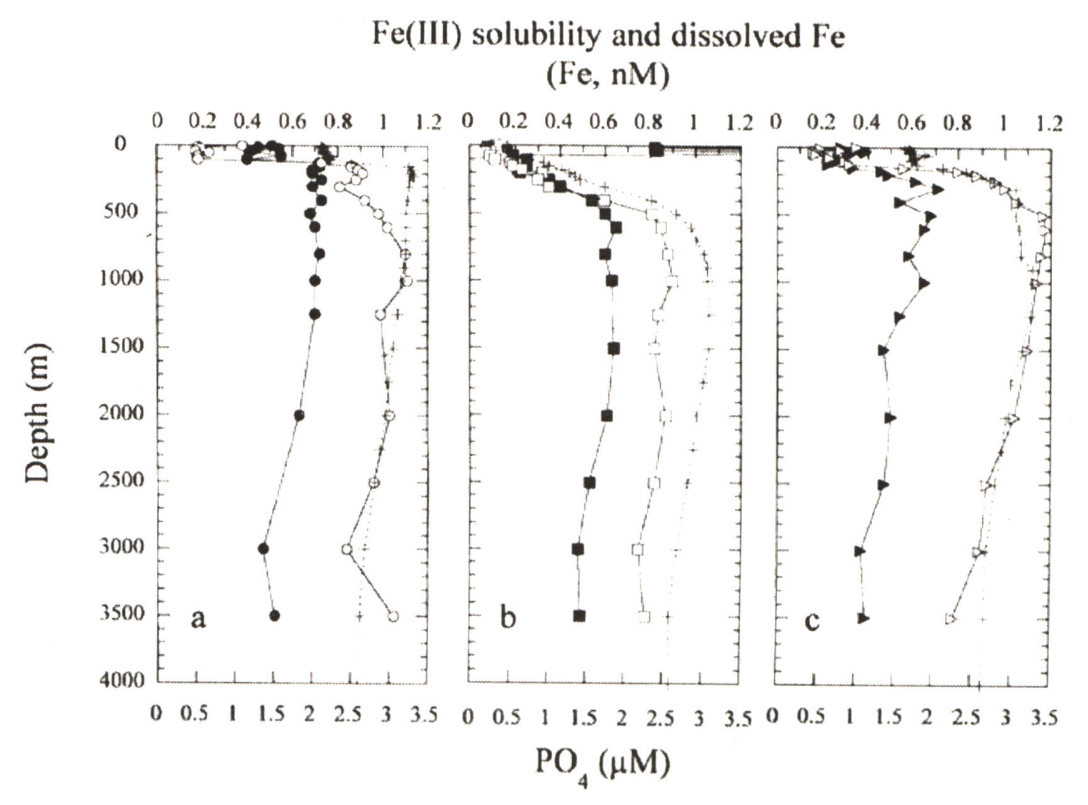

Fig. 3 Vertical distributions of Fe(III) solubility (solid signs), dissolved Fe (open signs) and PO4 concentrations (pluses) at 0-3500 m depth at stations (a) A, (b) B, and (c) C in the northwestern North Pacific

\section{BIOAVAILABLE IRON IN SEAWATER}

Iron is an essential micronutrient for phytoplankton growth, as an important component of such biochemical processes as photosynthetic and respiratory electron transport, nitrate and nitrite reduction, chlorophyll synthesis, and a number of other biosynthetic or degradative reactions (Weinberg, 1989; Geider and Roche, 1994). For example, several studies have documented the effect of iron on the uptake of $\mathrm{NO}_{3}{ }^{-}$uptake rate by addition of iron (Doucette and Harrison, 1991; Price et al., 1991). In oxic seawater, however, iron is present predominantly in the insoluble (extremely low solubility). Therefore, phytoplankton growth is controlled by the $\mathrm{Fe}(\mathrm{III})$ solubilities and the iron dissolution rates of colloidal $\mathrm{Fe}$ (III) phases (Wells et al., 1983; Rich and Morel, 1990; Kuma and Matsunaga, 1995). The availability of colloidal Fe(III) to provide a source of iron for phytoplankton is related to the thermodynamic 
stability and kinetic lability of the colloidal Fe(III) phases, which probably control the uptake rate of iron by phytoplankton. In addition, a number of studies pointed out that the $\mathrm{Fe}$ (III) complexation with natural organic ligands is possible in coastal and oceanic waters (e.g. Rue and Bruland, 1995, 1997; Kuma et al., 1996, 1998; van den Berg, C. M. G., 1995). The natural organic ligands may play an important role in biological availability of iron in seawater.

Many bioassays conducted with algae and bacteria have demonstrated that toxicity, nutrition and uptake of trace metals (such as $\mathrm{Zn}, \mathrm{Cu}, \mathrm{Mn}, \mathrm{Cd}$ and $\mathrm{Fe}$ ) are primarily a function of the free-ion concentration (or activity) of metal, $\left[\mathrm{M}^{\mathrm{Z+}}\right]$, in the artificial external medium (e.g. Sunda and Guillard, 1976; Anderson and Morel, 1982). This has led to the formulation of the "free-ion activity model (FIAM, Fig. 4)" (Tessier et al., 1994; Campbell, 1995). According to this model the physiological effect on an alga is proportional to the free-ion activity rather than to the total dissolved metal concentration, $[\mathrm{M}]_{\mathrm{t}}$, or to the complexed metal concentration, $[\mathrm{ML}]$. Although the calculated free ferric ion activity, $\left[\mathrm{Fe}^{3+}\right]$, provides a useful approximation of the availability of iron for uptake in the presence of synthetic chelators, the quantity of total inorganic $\mathrm{Fe}(\mathrm{III})$ species (dominantly the hydrolysis products $\mathrm{Fe}(\mathrm{OH})_{2}{ }^{+}$, $\mathrm{Fe}(\mathrm{OH})_{3}{ }^{\circ}$, and/or $\mathrm{Fe}(\mathrm{OH})_{4}{ }^{-}$in seawater, Fig. 1), [Fe(III)'], represents the actual instantaneous availability of iron for uptake at a given $\mathrm{pH}$. The iron uptake rate by phytoplankton is related to the computed equilibrium concentration of $\mathrm{Fe}^{3+}$ in seawater and is actually dependent on the concentration of dissolved inorganic Fe(III) species ([Fe(III)'], Fig. 5), which is proportional to $\left[\mathrm{Fe}^{3+}\right]$ (Anderson and Morel 1982; Hudson and Morel 1990; Campbell 1995; Sunda and Huntsman 1995; Sunda 2001). Therefore, the iron uptake of phytoplankton is limited by the equilibrium concentration of Fe(III)' (approximately $0.1 \mathrm{nmol} \mathrm{L}^{-1}$, Fig. 1 and 5) with particulate $\mathrm{Fe}(\mathrm{III})$ hydroxide in seawater if the dissolution rate of particulate $\mathrm{Fe}(\mathrm{III})$ is slow in relation to the further demands of the phytoplankton.
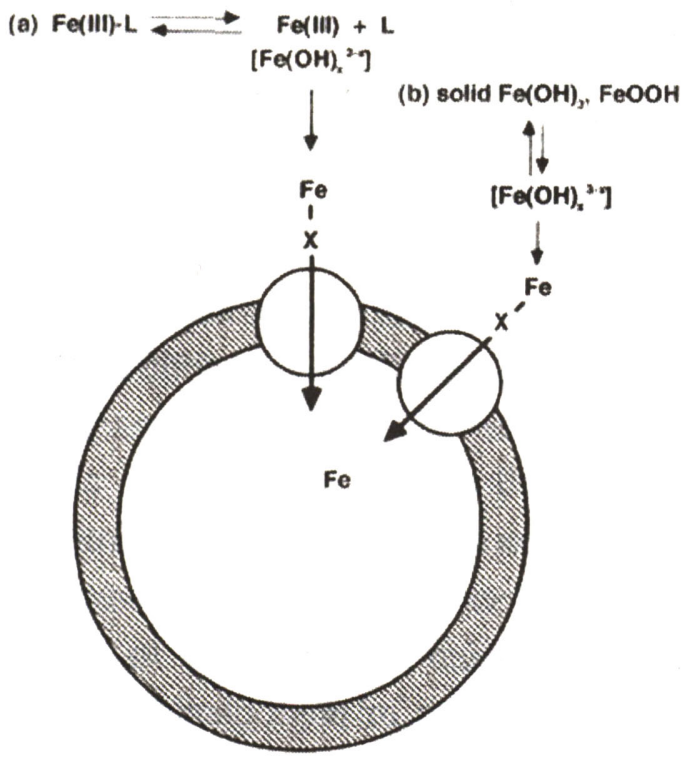

Fig 4 Free-ion activity model (FIAM) of Fe(III) uptake via the complexation of the Fe ion to cell surface uptake sites from labile hydrophilic organic-Fe(III) complexes (a) and solid Fe(III) hydroxide (b) in solution (Tessier et al, 1994; Campbell, 1995) 
In previous studies (Kuma et al. 1999, 2000), it has been suggested that the natural organic-Fe(III) complexes and acidic Fe(III) supplied by riverine and eolian inputs play an important role in supplying supersaturated bioavailable Fe(III)', above the equilibrium concentration of $\mathrm{Fe}(\mathrm{III})$ ', in estuarine mixing systems and coastal waters through its dissociation and hydrolytic precipitation at high $\mathrm{pH}$ of seawater and high levels of seawater cations (Stumm and Morgan 1996). The following exchange reaction between organic-Fe(III) complex and major alkaline earth metals (such as $\mathrm{Ca}^{2+}$ and $\mathrm{Mg}^{2+}$ ) in seawater is one of the most important processes resulting in dissociation of organic-Fe(III) complexes and subsequent $\mathrm{Fe}(\mathrm{III})$ hydrolytic precipitation:

$$
\mathrm{Fe}(\mathrm{III})-\mathrm{L}+\mathrm{Ca}^{2+} \underset{(1)}{\rightarrow} \mathrm{Ca}-\mathrm{L}+\mathrm{Fe}(\mathrm{III}) \underset{(2)}{\rightarrow} \text { solid am-Fe(III) } \quad \text { (Process I) }
$$

where reaction (1) represents metal exchange of $\mathrm{Fe}(\mathrm{III})-\mathrm{L}$ by $\mathrm{Ca}^{2+}$ and (2) is $\mathrm{Fe}$ (III) hydrolytic precipitation. $\mathrm{Fe}$ (III)-L and $\mathrm{Ca}-\mathrm{L}$ are dissolved $\mathrm{Fe}(\mathrm{III})$ and $\mathrm{Ca}$ complexed by organic ligand $\mathrm{L}$ (such as EDTA and fulvic acid), respectively, and Fe(III)' is dissolved Fe(III) not complexed with $\mathrm{L}$ and includes all the inorganic $\mathrm{Fe}(\mathrm{III})$ species. The high concentration of alkaline earth cations in seawater probably caused the dissolution of organic Fe(III) complexes through the metal exchange reaction. In estuarine and coastal waters, the natural dissolved organic-Fe(III) complexes supplied by riverine input such as fulvic-Fe(III) may play an important role in the supply of biological available iron by heightening the dissolved inorganic Fe(III) concentration, [Fe(III)'], through the dissociation of organic-Fe(III) complexes during mixing with seawater (Kuma et al., 1999).

In addition, two possible mechanisms by which [Fe(III)L] may be made generally accessible to phytoplankton are via a cell-surface reduction process, such as the use of a plasma membrane ferrireductase (Hutchins et al., 1999; Maldonado and Price, 1999), and photochemical cycling (Wells and Mayer, 1991; Johnson et al., 1994; Kuma et al., 1995). In both cases, reduced Fe(II) readily dissociates from the ligand, L, and is then acquired by a porter site (Rue and Bruland, 1997). In addition, photoproduced bioavailable Fe(II)' in seawater is rapidly oxidized and hydrolyzed to the bioavailable $\mathrm{Fe}(\mathrm{III})$ ' species (Millero et al., 1987; Kuma et al., 1995). The mechanism can be summarized as

$$
\mathrm{Fe}(\mathrm{III})-\mathrm{L} \underset{(1)}{\rightarrow} \mathrm{Fe}(\mathrm{II})^{\prime} \underset{(2)}{\rightarrow} \mathrm{Fe}(\mathrm{III})^{\prime} \underset{(3)}{\rightarrow} \text { solid am-Fe(III) (Process II) }
$$

where reaction (1) represents cell-surface reduction or photoreduction of organic-Fe(III) complexes, (2) represents oxidation of $\mathrm{Fe}(\mathrm{II})$ and then hydrolysis, and (3) is $\mathrm{Fe}$ (III) hydrolytic precipitation. Extremely high concentration of supersaturated inorganic $\mathrm{Fe}$ [Fe': $\mathrm{Fe}(\mathrm{III}){ }^{\text {' or }}$ $\left.\mathrm{Fe}(\mathrm{II})^{\prime}\right]$ species above the equilibrium concentration in seawater induces the highest iron uptake rate (Fig. 5) and highest growth of phytoplankton. However, apparent exceptions to the FIAM exist; for example, specific transport ligands, such as siderophores or lipophilic metal complexes, may be directly utilized by cells. The diffusion across a membrane by lipophilic organic metal complexes is an uptake mechanism for certain metals, such as $\mathrm{Cu}$ and 
$\mathrm{Ni}$, in addition to the uptake of free metal ions (Phinney and Bruland, 1994; Campbell, 1995).

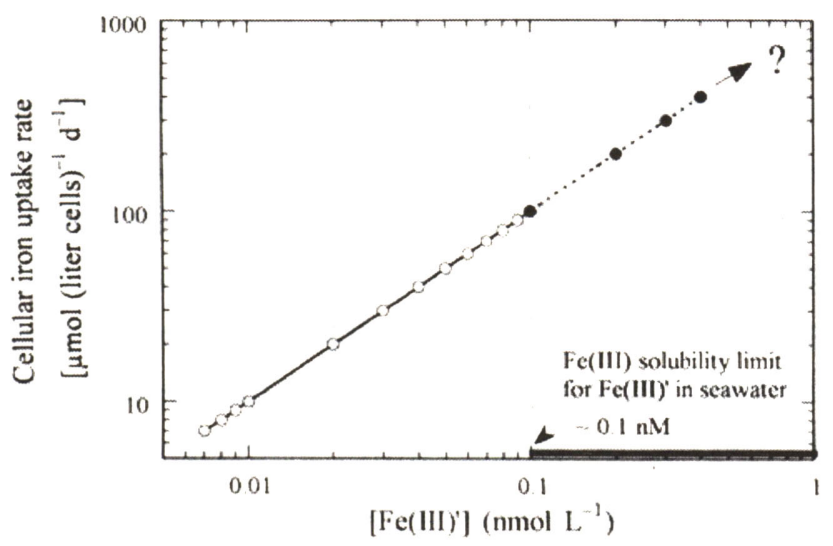

Fig. 5 Theoretical interrelationship between concentration of inorganic Fe(III) species and cellular iron uptake rate by phytoplankton

\section{BIOLOGICAL IMPACT OF IRON FROM THE AMUR RIVER ON THE PRIMARY PRODUCTION IN THE OKHOTSK SEA}

In section 3, it has been suggested that the natural organic-Fe(III) complexes, such as fulvic-Fe(III) complex, supplied by riverine input from the Amur River play an important role in supplying supersaturated bioavailable Fe(III)' in estuarine mixing systems and coastal waters in the Okhotsk Sea through its dissociation and hydrolytic precipitation at high $\mathrm{pH}$ of seawater and high levels of seawater cations. The metal-exchange reaction of fulvic-Fe(III) complex by major alkaline earth metals (such as $\mathrm{Ca}^{2+}$ and $\mathrm{Mg}^{2+}$ ) in seawater is one of the most important processes supplying supersaturated bioavailable Fe(III)' (Process I). In addition, photoreductive dissociation of natural dissolved fulvic-Fe(III) complex in seawater may increase bioavailable $\mathrm{Fe}^{\prime}$ (photoproduced bioavailable $\mathrm{Fe}$ (II)' and oxidized to the bioavailable Fe(III)' species) concentrations (Process II) that readily meet the growth demand of marine phytoplankton in the Okhotsk Sea. Therefore, the natural dissolved fulvic-Fe(III) complexes supplied from the Amur River into the Okhotsk Sea may play an important role in the supply of biological available iron by heightening the dissolved inorganic $\mathrm{Fe}$ concentration ([Fe'] $\left.=\left[\mathrm{Fe}(\mathrm{II})^{\prime}\right]+\left[\mathrm{Fe}(\mathrm{III})^{\prime}\right]\right)$ through the dissociation of fulvic-Fe(III) complexes. These above results have significant implications for the high primary productivity in the Okhotsk Sea. 


\section{REFERENCES}

Anderson M. A. and Morel F. M. M.(1982): The influence of aqueous iron chemistry on the uptake of iron by the coastal diatom. Thalassiosira weissflogii. Limnol. Oceanogr., 27, 789-813.

Archer D. E. and Johnson K. S.(2000): A model of the iron cycle in the ocean. Global Biogeochem. Cycles, 14, 269-279.

Boye M. and van den Berg C. M. G.(2000): Iron availability and the release of ironcomplexing ligands by Emiliania Huxley. Mar. Chem., 70, 277-287.

Boye M., van den Berg C. M. G., de Jong J. T. M., Leach H., Croot P. and de Baar H. J. W. (2001): Organic complexation of iron in the Southern Ocean. Deep-Sea Res. I, 48, 1477-1497.

Byrne R. H. and Kester D. R.(1976): Solubility of hydrous ferric oxide and iron speciation in seawater. Mar. Chem., 4, 255-274.

Campbell P. G. C.(1995): Interaction between trace metals and aquatic organisms: a critique of the free-ion activity model. In: Tessier, A., Turner, D. R. (Eds.), Metal speciation and bioavailability in aquatic systems, Wiley, New York, 45-102.

Doucette G. J. and Harrison P. J.(1991): Aspects of iron and nitrogen nutrition in the red tide dinoflagellate Gymnodinium sanguineum. II. Effects of iron depletion and nitrogen source on iron and nitrogen uptake. Mar. Biol., 110, 175-182.

Geider R. J. and Roche J. L.(1994): The role of iron in phytoplankton photosynthesis, and the potential for iron-limitation of primary productivity in the sea. Photosynthesis Res., 39, 275-301.

Gledhill M., van den Berg C. M. G., Nolting R. F. and Timmermans K. R.(1998): Variability in the speciation of iron in the northern North Sea. Mar. Chem., 59, 283-300.

Hayase K. and Shinozuka N.(1995): Vertical distribution of fluorescent organic matter along with AOU and nutrients in the equatorial Central Pacific. Mar. Chem., 48, 283-290.

Hudson R. J. M. and Morel F. M. M.(1990): Iron transport in marine phytoplankton: kinetics of cellular and medium coordination reactions. Limnol. Oceanogr., 35, 1002-1020.

Hutchins D. A., Witter A. E., Butler A. and Luther G. W. III(1999): Competition among marine phytoplankton for different chelated iron species. Nature, 400, 858-861.

Johnson K. S., Coale K. H., Elrod V. A. and Tindale N. W.(1994): Iron photochemistry in seawater from the equatorial Pacific. Mar. Chem., 46, 319-334.

Johnson K. S., Gordon R. M. and Coale K. H.(1997a): What controls dissolved iron concentrations in the world ocean? Mar. Chem., 57, 137-161.

Johnson K. S., Gordon R. M. and Coale K. H.(1997b): What controls dissolved iron concentrations in the world ocean? Authors' closing comments. Mar. Chem., 57, 181-186.

Kuma K. and Matsunaga K.(1995): Availability of colloidal ferric oxides to coastal marine phytoplankton. Mar. Biol., 122, 1-11.

Kuma K., Nakabayashi S. and Matsunaga K.(1995): Photoreduction of Fe(III) by hydroxycarboxylic acid in seawater. Water Res., 29, 1559-1569. 
Kuma K., Nishioka J., and Matsunaga K. (1996): Controls on iron(III) hydroxide solubility in seawater: The influence of $\mathrm{pH}$ and natural organic chelators. Limnol. Oceanogr., 41, 396-407.

Kuma K., Katsumoto A., Kawakami H., Takatori F., and Matsunaga K. (1998): Spatial variability of $\mathrm{Fe}$ (III) hydroxide solubility in the water column of the northern North Pacific Ocean. Deep-Sea Res. I, 45, 91-113.

Kuma K., Tanaka J., and Matsunaga K. (1999): Effect of natural and synthetic organic$\mathrm{Fe}(\mathrm{III})$ complexes in an estuarine mixing model on iron uptake and growth of a coastal marine diatom, Chaetoceros sociale. Mar. Biol., 134, 761-769.

Kuma K., Tanaka J., Matsunaga K., Matsunaga K.(2000): Effect of hydroxamate ferrisiderophore complex (ferrichrome) on iron uptake and growth of a coastal marine diatom, Chaetoceros sociale. Limnol. Oceanogr., 45, 1235-1244.

Kuma K., Isoda Y., and Nakabayashi S. (2003): Control on dissolved iron concentrations in deep waters in the western North Pacific: Iron(III) hydroxide solubility. J. Geophys. Res., 108(C9), 3289, doi:10.1029/2002JC001481.

Liu X. and Millero F. J. (1999): The solubility of iron hydroxide in sodium chloride solutions. Geochim. Cosmochim. Acta, 63, 3487-3497.

Liu X. and Millero F. J. (2002): The solubility of iron in seawater. Mar. Chem., 77, 43-54.

Maldonado M. T. and Price N. M. (1999): Utilization of iron bound to strong organic ligands by plankton communities in the subarctic Pacific Ocean. Deep-Sea Res. II, 46, 2447-2473

Millero F. J., Sotolongo S. and Izaguirre M. (1987): The oxidation of Fe(II) in seawater. Geochim. Cosmochim. Acta, 51, 793-801.

Millero F. J. (1996): Chemical Oceanography, 2nd ed., 469, CRC press, New York.

Millero F. J. (1998): Solubility of Fe(III) in seawater. Earth Planet Sci. Lett., 154, 3232-329.

Nakabayashi S., Kusakabe M., Kuma K. and Kudo I. (2001): Vertical distributions of iron(III) hydroxide solubility and dissolved iron in the northwestern North Pacific Ocean. Geophys. Res. Lett., 28, 4611-4614.

Nakabayashi S., Kuma K., Sasaoka K., Saitoh S., Mochizuki M., Shiga N. and Kusakabe M. (2002): Variation in iron(III) solubility and iron concentration in the northwestern North Pacific Ocean. Limnol. Oceanogr., 47, 885-892.

Phinney J. T. and Bruland K. W. (1994): Uptake of lipophilic organic $\mathrm{Cu}, \mathrm{Cd}$, and $\mathrm{Pb}$ complexes in the coastal diatom Thalassiosira weissflogii. Environ. Sci. Technol., 28, 1781-1790.

Price N. W., Andersen L. G. and Morel F. M. M. (1991): Iron and nitrogen nutrition of equatorial Pacific plankton. Deep-Sea Res., 38, 1361-1378.

Rich H. W. and Morel F. M. M. (1990): Availability of well-defined iron colloids to marine diatom Thalassiosira weissflogii. Limnol. Oceanogra., 35, 652-662.

Rue E.L. and Bruland K. W. (1995): Complexation of iron(III) by natural organic ligands in the Central North Pacific as determined by a new competitive ligand equilibration/adsorptive cathodic stripping voltammetric method. Mar. Chem., 50, 117-138. 
Rue E.L. and Bruland K. W. (1997): The role of organic complexation on amoient iron chemistry in the equatorial Pacific Ocean and the response of a mesoscale iron addition experiment. Limnol. Oceanogr., 42, 901-910.

Stumm W. and Morgan J. J. (1996): Aquatic Chemistry, 1022, Wiley, New York.

Sunda W. G. and Guillard R. R. L. (1976): The relationship between cupricion activity and the toxicity of copper to phytoplankton. J. Mar. Res., 34, 511-529.

Sunda W. G. and Huntsman S. A. (1995): Iron uptake and growth limitation in oceanic and coastal phytoplankton. Mar. Chem., 50, 189-206.

Sunda W. G. (2001): Bioavailability and bioaccumulation of iron in the sea. In:Turner, D. R., and K. A. Hunter (Eds.), The Biogeochemistry of Iron in Seawater, Wiley, New York, 41-84.

Tani H., Nishioka J., Kuma K., Takata H., Yamashita Y., Tanoue E. and Midorikawa T. (2003): Iron(III) hydroxide solubility and humic-type fluorescent organic matter in the deep water column of the Okhotsk Sea and the northwestern North Pacific Ocean. Deep-Sea Res. Part I, 50, 1063-1078.

Tessier A., Buffle J. and Campbell P. G. C. (1994): Uptake of trace metals by aquatic organisms. In: Buffle, J., R. R. de Vitre (Eds.), Chemical and biological regulation of aquatic systems, Lewis Publishers, Boca Raton, Florida, 197-230.

van den Berg C. M. G. (1995): Evidence for organic complexation of iron in seawater. Mar. Chem., 50, 139-157.

Waite T. D. (2001): Thermodynamics of the iron system in seawater. In:Turner, D. R., and K. A. Hunter (Eds.), The Biogeochemistry of Iron in Seawater, Wiley, New York, 291-342.

Weinberg E. D. (1989): Cellular regulation of iron assimilation. Q. Rev. Biol., 64, 261-290.

Wells M. L., Zorkin N. G. and Lewis A. G. (1983): The role of colloid chemistry in providing a source of iron to phytoplankton. J. Mar. Res., 41, 731-746.

Wells M. L. and Mayer L. M. (1991): The photoconversion of colloidal iron oxyhydroxides in seawater. Deep-Sea Res., 38, 1379-1395.

Wilhelm S. W. and Trick C. G. (1994): Iron-limited growth of cyanobacteria: Multiple siderophore production is a common response. Limnol. Oceanogr., 39, 1979-1984.

Witter A. E., Hutchins D. A., Butler A. and Luther G. W. (2000): Determination of conditional stability constants and kinetic constants for strong model Fe-binding ligands in seawater. Mar. Chem., 69, 1-17. 